\title{
Evolutionary patterns of proteinase activity in attine ant fungus gardens
}

\author{
Tatyana A Semenova ${ }^{1,2,3}$, David P Hughes ${ }^{1,4}$, Jacobus J Boomsma' ${ }^{1}$ Morten Schiøtt ${ }^{1 *}$
}

\begin{abstract}
Background: Attine ants live in symbiosis with a basidiomycetous fungus that they rear on a substrate of plant material. This indirect herbivory implies that the symbiosis is likely to be nitrogen deprived, so that specific mechanisms may have evolved to enhance protein availability. We therefore hypothesized that fungal proteinase activity may have been under selection for efficiency and that different classes of proteinases might be involved.

Results: We determined proteinase activity profiles across a wide $\mathrm{pH}$ range for fungus gardens of 14 Panamanian species of fungus-growing ants, representing eight genera. We mapped these activity profiles on an independently obtained molecular phylogeny of the symbionts and show that total proteinase activity in lower attine symbionts peaks at ca. pH 6. The higher attine symbionts that have no known free-living relatives had much higher proteinase activities than the lower attine symbionts. Their total in vitro proteinase activity peaked at pH values around 5, which is close to the $\mathrm{pH}$ that the ants maintain in their fungus gardens, suggesting that the $\mathrm{pH}$ optimum of fungal proteinases may have changed after the irreversible domestication of evolutionary more derived fungal symbionts. This notion is also supported by buffering capacities of fungus gardens at pH 5.2 being remarkably high, and suggests that the fungal symbiont actively helps to maintain garden acidity at this specific level. Metalloproteinases dominated the activity profiles of lower attine gardens and may thus represent the ancestral type of proteinase production, whereas serine proteinase activity dominated the activity profiles of the higher attine gardens reared by Trachymyrmex and Sericomyrmex, suggesting that there may be trade-offs in the production of these enzyme classes. Remarkably, the single symbiont that is shared by species of the crown group of Atta and Acromyrmex leaf-cutting ants mostly showed metalloproteinase activity, suggesting that recurrent changes in enzyme production may have occurred throughout the domestication history of fungus-garden symbionts.

Conclusions: Proteinase pH optima and buffering capacities of fungal symbionts appear to have evolved remarkable adaptations to living in obligate symbiosis with farming ants. Although the functional roles of serine and metalloproteinases in fungus gardens are unknown, the differential production of these classes of proteolytic enzymes suggest that substrate specificity may be important and that trade-offs may prevent the simultaneous upregulation of both classes of enzymes.
\end{abstract}

\section{Background}

Organisms that engage in an obligate mutualistic lifestyle often experience a drastic change in environmental conditions. Well known examples are symbiotic bacteria in the rumen of ungulates and the mitochondria in eukaryotic cells, which function under quite different growth conditions than free-living bacteria, and have

\footnotetext{
* Correspondence: mschiott@bio.ku.dk

${ }^{1}$ Centre for Social Evolution, Department of Biology, University of

Copenhagen, Universitetsparken 15, DK-2100 Copenhagen, Denmark

Full list of author information is available at the end of the article
}

genomes that became modified or reduced in response to these specialized dependent life styles [1,2]. However, the expression of derived symbiotic traits is difficult to study in endosymbiotic bacteria, because they can normally not be grown on artificial media [3] or otherwise be studied separately from the host. This is easier in obligate ectosymbioses where hosts and symbionts can often survive and function without their partner-mutualist for at least a short period, and where relatively pure samples of symbiont biomass can often be obtained and analyzed.

\section{Biomed Central}

() 2011 Semenova et al; licensee BioMed Central Ltd. This is an Open Access article distributed under the terms of the Creative Commons Attribution License (http://creativecommons.org/licenses/by/2.0), which permits unrestricted use, distribution, and reproduction in any medium, provided the original work is properly cited. 
Attine ants live in obligate mutualistic association with specific fungi that they rear for food in underground gardens. The cultivated fungi mostly belong to the tribe Leucocoprini (Basidiomycotina: Agaricales: Agaricaceae) $[4,5]$ which primarily consists of free-living saprotrophic genera that grow in the lower litter layer of forest floors, usually characterized by high $\mathrm{pH}$ levels [6] The ants supply their mutualistic fungi with substrate and protect their gardens from infections [5]. One of the defense mechanisms to control diseases is the secretion of the ant's metapleural glands [7-10], which generates acidic conditions in fungus gardens, discouraging microbial growth relative to the surrounding soil with higher $\mathrm{pH}$. Acetic acid is being produced in the fungus gardens, but this has to be tightly regulated as it has the potential to inflict more harm to the symbiont than to alien fungi [10]. The domestication of fungal symbionts by the ants may therefore have required specific adaptations for growing under lower but more controlled $\mathrm{pH}$ conditions, both in terms of $\mathrm{pH}$ buffering and with regard to the activity optima of the extracellular enzymes that are produced to degrade the substrate that the ants collect.

Nitrogen is a limiting factor for growth and maintenance in many organisms, particularly those living on a herbivorous diet as the attine ants indirectly do. Recent findings show that leaf-cutting ants partly overcome nitrogen limitation by living in association with $\mathrm{N}_{2}$-fixing bacteria that may supply as much as $50 \%$ of a colony's nitrogen requirements [11]. Such bacterial nitrogen will be incorporated into proteins, so that the fungal symbionts of the ants must secrete proteinases to digest these into amino acids that can be assimilated. The fungal symbiont is also likely to compete for nitrogen with other, non mutualistic microorganisms living in the fungus garden $[12,9,13]$, imposing further selection for effective protein degradation by the fungal symbiont. Finally, proteolytic enzymes are known to be strongly $\mathrm{pH}$ dependent, so in order to have effective protein degradation the $\mathrm{pH}$ optimum of the proteolytic enzymes should ideally match the $\mathrm{pH}$ of the fungus garden.

Several studies have been devoted to the role of $\mathrm{pH}$ in controlling in vitro proteolytic enzyme secretion in fungi [14], but to our knowledge in vivo studies of $\mathrm{pH}$-dependent proteolytic enzyme activities in fungi have not been done. The objective of our present study was thus threefold: 1. To use the unique growth form of ant fungus gardens to determine the feasibility of $\mathrm{pH}$ buffering studies in fungi, 2. To determine the $\mathrm{pH}$ activity optima of different classes of extracellular proteinases across a series of genera and species of fungus-growing ants, and 3. To map the observed differences on an independently obtained phylogenetic tree of the fungal symbionts to obtain insight in the evolutionary pathways that may have generated differences in $\mathrm{pH}$-dependent activities of proteinases.

\section{Results}

The $\mathrm{pH}$ conditions of fungus gardens and their buffering capacity

All 29 attine ant colonies used in this study (see Table 1 for details) displayed the same $\mathrm{pH}(5.2 \pm 0.1)$ for $1: 1$ water extracts taken from the middle layer of the fungus gardens. Adding acid/alkaline solutions to the fungus garden extracts did not noticeable change the color of $\mathrm{pH}$ paper compared to controls (data not shown) indicating that all tested fungus gardens exhibited approximately the same buffering strength.

Approximate buffering capacities for attine symbionts and non-symbiotic basidiomycetous fungi (Table 2) showed that fungus garden symbionts and plated L. gongylophorus (ca 6 - 22 mekv/L) tended to have higher buffering capacities than free-living fungi (ca 2 - 10 mekv/L) $\left(\mathrm{t}_{23}=-8.6, \mathrm{p}<0.001\right)$. The buffering capacity of plated fungi did not depend on the composition of the cultivation media. The relationship between the $\mathrm{pH}$ and the amount of added base was approximately linear ( $\mathrm{R}^{2}$ not less than 0.976 , data not shown) suggesting that all measurements were performed in the $\mathrm{pH}$ zone close to the buffer point of the tested solutions where they exhibit their maximal buffering capacity [15].

\section{Differential production of proteinase classes across fungus gardens}

All tested colonies displayed significant proteinase activity (Table 1 ). The mean total activity values \pm SE were $127 \pm$ $11,270 \pm 19$ and $360 \pm 28 \mathrm{U} \cdot 10^{3}$ ( $\pm \mathrm{SE}$ ) for lower attine, higher attine and leaf-cutting ant gardens, respectively, which implies that total proteinase activity increases with the degree of evolutionary "advancement" of the symbiosis. However, the garden of Apterostigma collare was an exception to this rule, expressing relatively high total proteinase activity compared to the other lower attine ants. This is remarkable as these ants rear a phylogenetically distant fungus, belonging to the family Pterulaceae, while all other attines cultivate fungi belonging to the Leucocoprini tribe of the family Agaricaceae [4,5].

Inhibition analyses revealed that proteinases belonging to all four catalytic classes could be detected in the fungus gardens (Table 1), but the activity of aspartic and cysteine proteinases was very low compared to the activity of serine- and metalloproteinases. This result was not unexpected as cysteine and aspartic proteinases are rarely produced by fungi $[16,17]$. The serine proteinases belonged to the subtilase-like superfamily as they were inhibited by PMSF, but not by TLCK and TPCK [18], and they displayed activity towards the chromogenic substrates Glp-AAL-pNa and Suc-AAPF-pNa, but not 
Table 1 Total and class-specific relative proteolytic activity and its $\mathrm{pH}$ optimum range measured in fungus gardens

\begin{tabular}{|c|c|c|c|c|c|c|c|c|c|c|}
\hline Ant species & $\begin{array}{l}\text { Colony } \\
\text { number }\end{array}$ & $\begin{array}{l}\text { Sample } \\
\text { number }\end{array}$ & Total activity & $\begin{array}{c}\mathrm{pH} \\
\text { optimum }\end{array}$ & $\begin{array}{l}\text { Metallo- } \\
\text { proteinase } \\
\text { activity }\end{array}$ & $\begin{array}{c}\mathrm{pH} \\
\text { optimum }\end{array}$ & $\begin{array}{l}\text { Serine } \\
\text { proteinase } \\
\text { activity }\end{array}$ & $\begin{array}{c}\mathrm{pH} \\
\text { optimum }\end{array}$ & $\begin{array}{l}\text { Aspartic } \\
\text { proteinase } \\
\text { activity }\end{array}$ & $\begin{array}{c}\text { Cysteine } \\
\text { proteinase } \\
\text { activity }\end{array}$ \\
\hline $\begin{array}{l}\text { Apterostigma } \\
\text { collare }\end{array}$ & Apcol1 & - & $630.0 \pm 18.3$ & & $593.0 \pm 13.3$ & & $1.7 \pm 0.5$ & & $16.0 \pm 1.0$ & $0.8 \pm 0.5$ \\
\hline \multirow[t]{2}{*}{$\begin{array}{l}\text { Myrmicocrypta } \\
\text { ednaella }\end{array}$} & Myred1 & 1 & $168.6 \pm 9.5$ & $6.2 \pm 0.11$ & $151.5 \pm 6.4$ & $6.0 \pm 0.04$ & $9.4 \pm 1.0$ & $\begin{array}{l}7.0 \pm \\
0.012\end{array}$ & - & $9.3 \pm 1.0$ \\
\hline & Myred2 & 2 & $165.2 \pm 9.2$ & & $104.0 \pm 5.0$ & & $50.1 \pm 6.3$ & & - & - \\
\hline \multirow{3}{*}{$\begin{array}{l}\text { Mycocepurus } \\
\text { smithii }\end{array}$} & Mycsmi9 & 3 & $114.0 \pm 9.0$ & $6.0 \pm 0.11$ & $101.6 \pm 4.8$ & $6.0 \pm 0.1$ & $5.3 \pm 1.0$ & & $4.1 \pm 1.0$ & $3.6 \pm 1.0$ \\
\hline & Mycsmi15 & 4 & $136.6 \pm 9.6$ & & $124.5 \pm 8.7$ & & $6.7 \pm 1.0$ & & - & - \\
\hline & Mycsmi32 & 5 & $153.0 \pm 10.7$ & & $148.7 \pm 8.5$ & & $2.8 \pm 1.0$ & & $1.3 \pm 1.0$ & - \\
\hline \multirow{3}{*}{$\begin{array}{l}\text { Cyphomyrmex } \\
\text { costatus }\end{array}$} & Cycos6 & 6 & $65.2 \pm 8.2$ & & $54.8 \pm 5.0$ & & $5.9 \pm 2.0$ & & $1.6 \pm 1.0$ & $1.6 \pm 0.8$ \\
\hline & $C y \cos 9$ & 7 & $61.3 \pm 5.0$ & $6.0 \pm 0.11$ & $47.4 \pm 4.5$ & $6.0 \pm 0.08$ & $3.3 \pm 1.0$ & & $3.1 \pm 1.0$ & $3.7 \pm 1.0$ \\
\hline & Cycos 16 & 8 & $112.5 \pm 9.0$ & & $90.8 \pm 4.3$ & & $19.0 \pm 3.2$ & & $2.8 \pm 1.0$ & - \\
\hline \multirow{3}{*}{$\begin{array}{l}\text { Cyphomyrmex } \\
\text { longiscapus }\end{array}$} & Cylon12 & 9 & $131.5 \pm 8.7$ & $6.0 \pm 0.09$ & $106.9 \pm 7.5$ & $6.0 \pm 0.1$ & $18.9 \pm 2.0$ & & $3.2 \pm 1.0$ & $3.2 \pm 1.1$ \\
\hline & Cylon5 & 10 & $140.6 \pm 9.8$ & & $131.0 \pm 5.2$ & & $6.4 \pm 2.0$ & & $3.7 \pm 1.0$ & - \\
\hline & Cylon24 & 11 & $146.5 \pm 9.0$ & & $132.5 \pm 9.0$ & & $6.6 \pm 2.4$ & & $5.2 \pm 1.4$ & - \\
\hline \multirow[t]{3}{*}{$\begin{array}{l}\text { Sericomyrmex } \\
\text { amabilis }\end{array}$} & Serama8 & 12 & $210.0 \pm 8.9$ & $\begin{array}{l}5.2 \pm \\
0.015\end{array}$ & $48.1 \pm 4.4$ & $5.0 \pm 0.1$ & $108.1 \pm 5.6$ & $\begin{array}{l}7.0 \pm \\
0.075\end{array}$ & $30.0 \pm 10.2$ & $29.0 \pm 6.4$ \\
\hline & Serama7 & 13 & $194.1 \pm 12.4$ & & $22.3 \pm 3.5$ & & $130.5 \pm 6.3$ & & $30 \pm 8.8$ & $26 \pm 7.2$ \\
\hline & Serama12 & 14 & $308.1 \pm 9.0$ & & $42.5 \pm 4.2$ & & $227.1 \pm 9.9$ & & $21.1 \pm 7.4$ & $23.4 \pm 5.2$ \\
\hline \multirow{4}{*}{$\begin{array}{l}\text { Trachymyrmex } \\
\text { cornetzi }\end{array}$} & Trcor1 & 15 & $310.3 \pm 10.3$ & & $262.9 \pm 9.1$ & & $49.4 \pm 4.0$ & & - & $3.2 \pm 1.0$ \\
\hline & Trcor3 & 16 & $333.4 \pm 9.5$ & & $211.5 \pm 7.4$ & & $46.1 \pm 4.2$ & & - & $78.0 \pm 5.5$ \\
\hline & Trcor4 & 17 & $257.4 \pm 9.2$ & $5.7 \pm 0.07$ & $92.4 \pm 7.2$ & $6.05 \pm 0.1$ & $138.4 \pm 8.3$ & $\begin{array}{l}5.7 \pm 0,1 \\
7.5 \pm 0.05\end{array}$ & $5.0 \pm 1.3$ & $22.1 \pm 4.6$ \\
\hline & Trcor10 & 18 & $155.0 \pm 9.6$ & $5.7 \pm 0.07$ & $131.9 \pm 7.12$ & $5.7 \pm 0.09$ & $7.7 \pm 1.0$ & & $7.14 \pm 2.1$ & $7.15 \pm 1.1$ \\
\hline \multirow[t]{2}{*}{$\begin{array}{l}\text { Trachymyrmex } \\
\text { sp. } 3\end{array}$} & Trsp3-3 & 19 & $201 \pm 9.1$ & $5.2 \pm 0.11$ & $35.0 \pm 9.8$ & $5.7 \pm 0.09$ & $\begin{array}{l}153.1 \pm \\
10.42\end{array}$ & $\begin{array}{l}7.5 \pm 0.09 \\
5.2 \pm 0.09\end{array}$ & $7.0 \pm 1.5$ & $8.4 \pm 2.2$ \\
\hline & Trsp3-6 & 20 & $249.7 \pm 9.4$ & & $33.5 \pm 7.4$ & & $199.2 \pm 9.0$ & & - & $20.0 \pm 7.8$ \\
\hline \multirow{3}{*}{$\begin{array}{l}\text { Trachymyrmex } \\
\text { zeteki }\end{array}$} & Trzet2 & 21 & $340.1 \pm 11.0$ & & $67.4 \pm 5.0$ & & $215.5 \pm 7.5$ & & - & $55.7 \pm 8.8$ \\
\hline & Trzet3 & 22 & $342.3 \pm 9.5$ & $5.2 \pm 0.1$ & $28.4 \pm 7.0$ & $5.2 \pm 0.09$ & $317.0 \pm 7.1$ & $\begin{array}{l}5.35 \pm \\
0.08\end{array}$ & - & - \\
\hline & Trzet6 & 23 & $340.1 \pm 8.9$ & & $70.6 \pm 6.0$ & & $261.5 \pm 9.0$ & & $1.39 \pm 1.5$ & $6.5 \pm 1.3$ \\
\hline $\begin{array}{l}\text { Acromyrmex } \\
\text { echinator }\end{array}$ & Acech322 & 24 & $323.3 \pm 10.0$ & $5.4 \pm 0.11$ & $227.5 \pm 10.6$ & $5.2 \pm 0.09$ & $66.5 \pm 6.4$ & $7.5 \pm 0.06$ & $18.5 \pm 6.3$ & - \\
\hline $\begin{array}{l}\text { Acromyrmex } \\
\text { octospinosus }\end{array}$ & Acoct1 & 25 & $454.2 \pm 15.2$ & & $322.1 \pm 12.5$ & & $64.2 \pm 5.5$ & & - & $56.2 \pm 6.0$ \\
\hline Atta colombica & Atcol1 & 26 & $332.1 \pm 14.8$ & & $227.5 \pm 10.5$ & & $66.5 \pm 6.02$ & & $18.5 \pm 4.6$ & - \\
\hline Atta sexdens & Atsex 1 & 27 & $390.0 \pm 13.5$ & & $300.6 \pm 11.6$ & & $35.7 \pm 9.0$ & & $18.4 \pm 6.3$ & $40.1 \pm 5.4$ \\
\hline $\begin{array}{l}\text { Atta cephalotes } \\
\text { phalotes }\end{array}$ & Atcep1 & 28 & $300.1 \pm 14.7$ & & $\begin{array}{l}193.1 \pm \\
13.06\end{array}$ & & $30.1 \pm 6.41$ & & $35.5 \pm 4.9$ & $50.1 \pm 6.6$ \\
\hline
\end{tabular}

One unit of relative proteolytic activity $(\mathrm{U})$ corresponds to $1^{*} 10^{(-3)}$ difference between treatment and control absorbance $\left(\mathrm{A}_{440}\right.$, at $\mathrm{t}^{\circ} \mathrm{C} 26^{\circ} \mathrm{C}, 1$ hour). The mean activity values are presented as $\mathrm{U}^{*} 10^{3} \pm \mathrm{SE}$.

to N-benzoyl-Arg-pNa [19]. The metalloproteinases could not be further identified.

The activities of the two dominant classes of proteinases varied considerably between fungus gardens (Figure 1), with lower attine symbionts having low activities for both classes and the basal higher attine- and leaf-cutting symbionts specializing in producing mostly only one class. Leaf-cutting ant gardens were characterized by high activity of metalloproteinases, similar (at least in relative activity) to the lower attine gardens, whereas the gardens of basal higher attine ants, with one exception, primarily showed serine proteinase activity (Figure 1). 
Table 2 Buffering capacity (means \pm SE in mekv/L) for free living fungi and fungus garden symbionts of attine ants

\begin{tabular}{|c|c|c|}
\hline Fungal species (family) & Buffering capacity, mekv/L & Sample size \\
\hline \multicolumn{3}{|l|}{ Free-living fungi, plated } \\
\hline \multirow[t]{2}{*}{ Agaricus bisporus (Agaricaceae) } & $9.6 \pm 1.08($ strain 1$)$ & 5 \\
\hline & $7.3 \pm 0.92$ (strain 2) & 5 \\
\hline Pleurotus ostreatus (Pleurotaceae) & $4.95 \pm 0.7$ & 5 \\
\hline Pleurotus pulmonarius (Pleurotaceae) & $3.1 \pm 0.12$ & 5 \\
\hline Lentinula edodes (Marasmiaceae) & $2.01 \pm 0.1$ & 5 \\
\hline \multicolumn{3}{|l|}{ Fungus garden symbiont, plated } \\
\hline Leucocoprinus gongylophorus (Agaricaceae) & $16.2 \pm 2.01$ & 3 \\
\hline \multicolumn{3}{|l|}{ Fungus garden symbiont, colony } \\
\hline Apterostigma collare, (Apcol1) & not measured* & \\
\hline Myrmicocrypta ednaella, (Myred2) & 21.92 & 3 \\
\hline Mycocepurus smithii, (Mycsmi32) & 21.89 & 3 \\
\hline Trachymyrmex cornetzi, (Trcor1) & 20.55 & 3 \\
\hline Sericomyrmex amabilis, (Serama7) & 16.74 & 3 \\
\hline Sericomyrmex amabilis, (Serama12) & $5.80^{* *}$ & 3 \\
\hline Acromyrmex echinator, (Acech322) & $17.93 \pm 1.54$ & 3 \\
\hline Acromyrmex octospinosus, (Acoct1) & 16.80 & 3 \\
\hline Atta colombica, (Atcol1) & 17.64 & 3 \\
\hline Atta cephalotes, (Atcep1) & 22.20 & 3 \\
\hline
\end{tabular}

* Buffering was observed on $\mathrm{pH}$ test papers only, but was comparable to the other fungal garden symbionts.

** This colony of Sericomyrmex amabilis (Serama12) had an unusually solid and humid garden structure compared to all other fungus gardens examined.

\section{Mapping proteolytic activity profiles on the phylogenetic tree of the fungal symbionts}

Mapping the $\mathrm{pH}$ optima curves of proteinase activity on the phylogenetic tree of the fungal symbionts (Figure 2) showed distinct correlations between symbiont clades and the classes of proteinases that were primarily active. High serine proteinase activity was typical for the symbionts of Sericomyrmex amabilis, Trachymyrmex sp3, and $T$. cf. zeteki, which formed a monophyletic group.

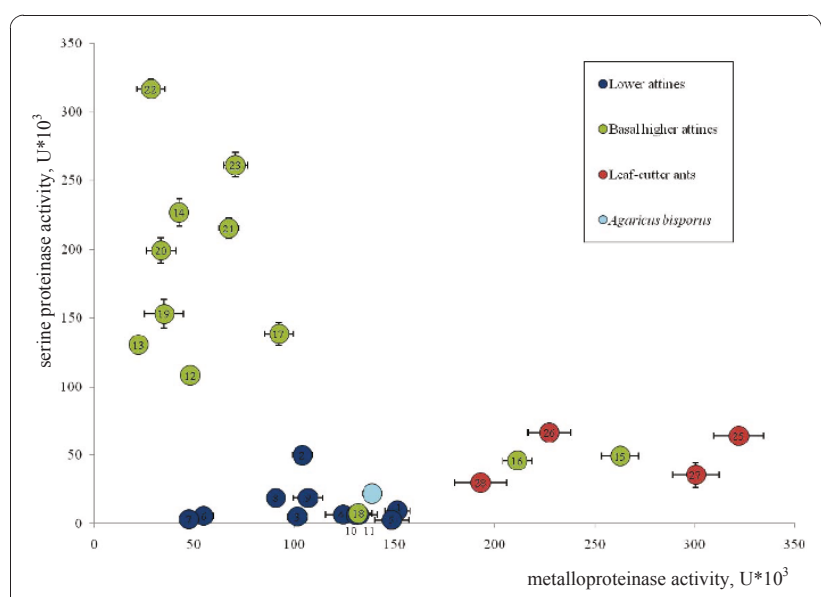

Figure 1 Fungal proteolytic activity (see Table 1) partitioned between serine- and metalloproteinases. Lower attine, basal higher attine and leaf-cutting ant activities are plotted in blue, green and red, respectively.
In contrast, the symbionts of $T$. cornetzi had a proteinase profile resembling that of the Acromyrmex and Atta leaf-cutting ants, and formed a sister group to the remaining Trachymyrmex and Sericomyrmex symbionts. The only exception to this pattern was one of the four symbionts of $T$. cornetzi (Trcor4), which had an intermediate proteinase profile with almost equal serine- and metalloproteinase activity, and which formed the most basal branch of the T. cornetzi clade of symbionts (number 17, Figure 2).

The $\mathrm{pH}$ optimum of total proteinase activity in the gardens reared by lower attines averaged $6.0 \pm 0.11$, while the peak of proteinase activity in basal higher attines and leaf-cutting ants colonies was closer to the pH levels (ca. 5) in the fungus gardens (Figure 3; Table 1$)\left(t_{36}=9.3, p<0.001\right)$, as one would expect when the higher attine fungus gardens would have become adapted to growing under more acidic conditions. However, in three of the four clades of higher attine and leaf-cutting symbionts, the total proteinases activity profiles between $\mathrm{pH} 5$ and 7 were remarkably flat, as serine proteinases became increasingly active at higher pHs (Figures 2 and 3). For example, the serine proteinases in Sericomyrmex amabilis colonies were most active at $\mathrm{pH}$ conditions of $7.0 \pm 0.05$, similar to lower attine gardens $(7.0 \pm 0.09)$ where serine proteinase activity is rarely seen, whereas an additional peak of serine proteinase activity at $\mathrm{pH} 5.2 \pm 0.11$ (different from the 7.0 mean above: $\left.\mathrm{t}_{6}=17.0, \mathrm{p}<0.001\right)$ was observed 


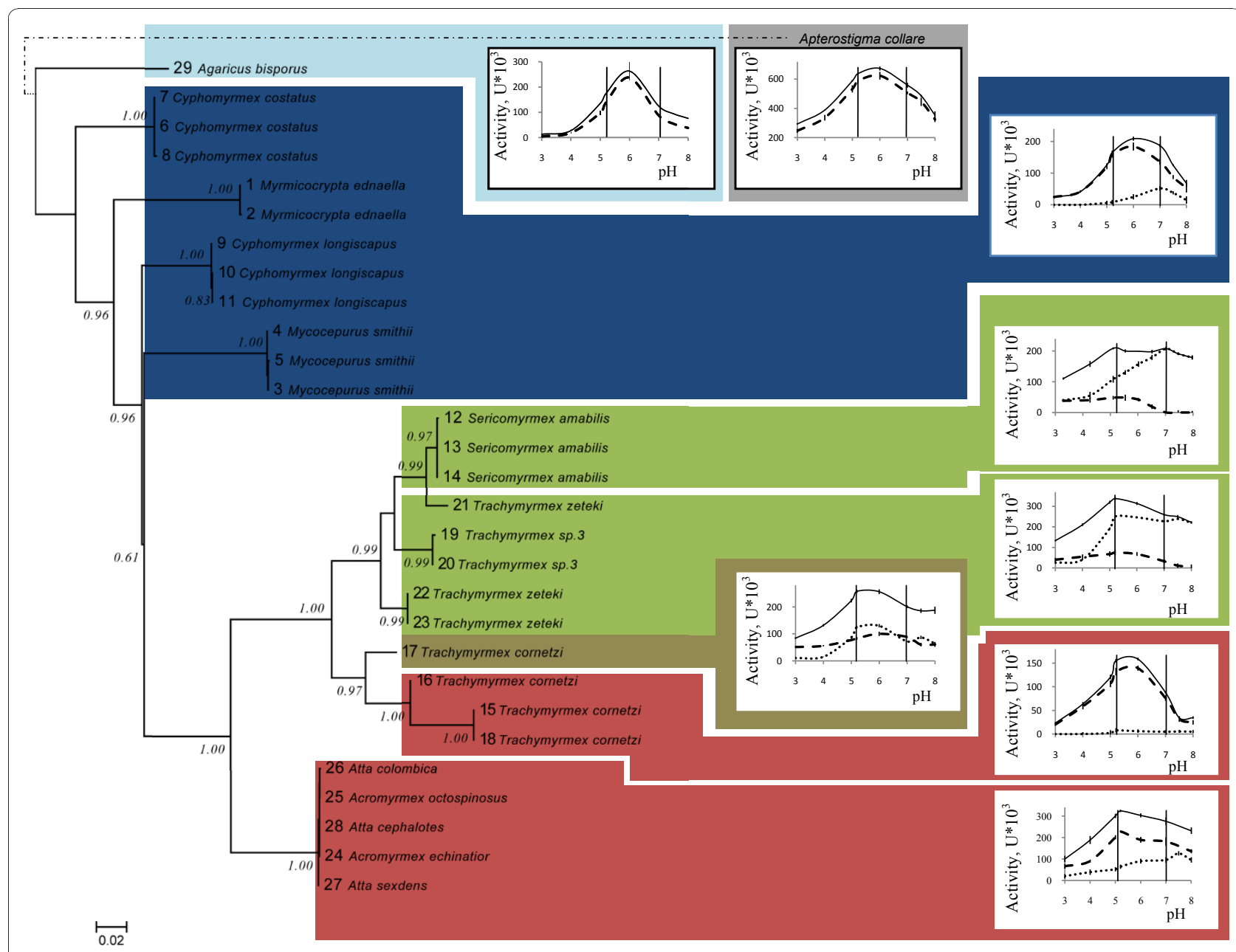

Figure 2 pH-dependent proteolytic enzyme activity profiles mapped on the fungal symbiont phylogeny. The pH optima curves concern total proteinase activity (solid lines) and metallo- and serine proteinase activity separately (dashed and dotted lines, respectively). Vertical lines on the graphs represent the respective $\mathrm{pH}$ conditions of fungus gardens (5.2) and the typical pH optimum for alkaline proteinases (7.0). The profiles of lower attines plus higher attines with mainly serine proteinase activity and higher attine and leaf-cutting ants with mainly metalloproteinase activity are outlined with blue, green and red backgrounds, respectively, to match color-coding in Figure 1. The single Trachymyrmex cornetzi garden with an intermediate proteinase profile is plotted against a brown background and the single Apterostigma collare colony rearing a pterulaceous fungal symbiont against a grey background. The numbering of fungus gardens corresponds to the numbers used in the Table 1. The Myrmicocrypta ednaella (Myred1) profile is representative for all lower attine gardens. The Sericomyrmex amabilis (Serama1) garden was chosen as illustrative example because it showed a relatively high metalloproteinase activity, so that a clearer pH profile could be obtained. For Trachymyrmex species with predominantly serine proteinase activity we plotted the average profile for Trachymyrmex sp3 (Trsp3-3) and Trachymyrmex cf. zeteki (Trzet3), which were very similar. As representatives of the basal higher attine and leaf-cutting ant symbionts with predominantly metalloproteinase activity we plotted gardens of colonies Trcor10 and Acech322 as gardens of other colonies with this symbiont displayed very similar profiles. The phylogenetic tree is based on the LSU rRNA and Elongation Factor 1-alpha genes, except for samples 20 and 23 for which only the LSU gene could be sequenced. Only aLRT (approximate likelihood ratio test) support values $>0.5$ are given.

for the symbionts of Trachymyrmex sp3 and T. cf. zeteki, but not for Sericomyrmex symbionts (Figures 2 and 3 and Table 1). Similar patterns were observed for metalloproteinases. The relatively low amounts produced in the symbionts of lower attine ants were most active under slightly acidic $\mathrm{pH}$ conditions $(6.0 \pm 0.11)$ and shifts towards more acidic optima were detected for the symbionts of Trachymyrmex cornetzi (5.6 \pm $0.09)\left(t_{4}=3.45, \mathrm{p}=0.026\right)$ and the leaf-cutting ants mutualists $(5.2 \pm 0.08)\left(t_{6}=10.0, \mathrm{p}<0.001\right)$ (Figures 2 and 3 and Table 1).

\section{Discussion}

Fungus-garden $\mathrm{pH}$ buffering capacity is remarkably high Acidification of the environment increases the difference between the extracellular surroundings and the intracellular milieu, so that compensating metabolic activities are required to maintain the $\mathrm{pH}$ within cells at the 


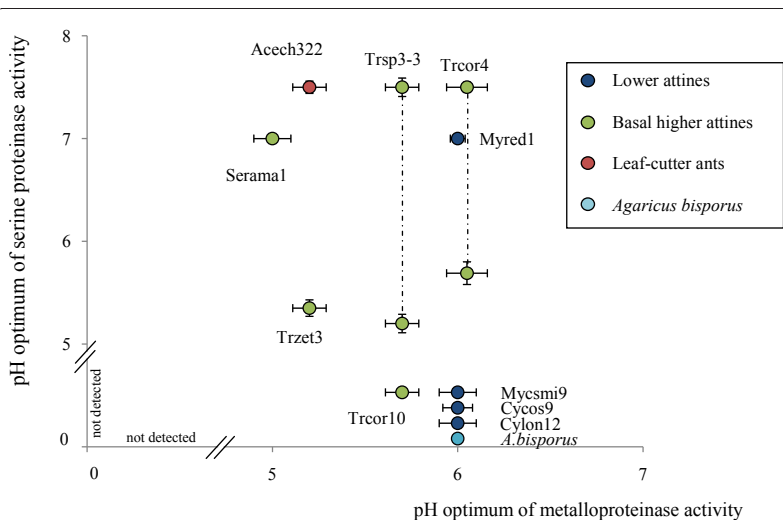

Figure 3 The class-specific $\mathrm{pH}$ optima for serine (vertical axis) and metalloproteinases (horizontal axis) for the fungus gardens in Table 1 for which both $\mathrm{pH}$ optima could be measured from the same samples. The vertical axis is interrupted to allow the pH-optimum to be plotted for metalloproteinase activity in gardens where serine proteinase activity could not be measured. The overall pattern indicates that $\mathrm{pH}$ optima for metalloproteinases are always between ca. 5 and 6, whereas serine proteinase pH optima tend to fall between 7 and 8 . All values are means \pm SEMs. Dotted lines connect observations for the same species. See Table 1 for details.

approximately neutral values that normally optimize growth and survival of fungal hyphae [20]. In vitro, these metabolic activities include the synthesis of $\mathrm{pH}$ regulating compounds and the modification of excreted compounds so they can function under acidic conditions $[21,22,14,23]$. This is particularly important for the extracellular proteolytic enzymes secreted by the fungal symbiont of the leaf-cutting ants, because these enzymes secure the decomposition of proteins that ultimately supply nitrogen to the ant colony [24,25].

Fungi are known to modify the environmental $\mathrm{pH}$ in vitro [14] and to regulate $\mathrm{pH}$ in vivo by secreting weak organic acids [23] with buffering properties [26,27]. However, fungi normally avoid natural habitats with unsuitable $\mathrm{pH}$ [6], possibly because of the metabolic costs of this type of adjustments in competition with more specifically $\mathrm{pH}$-adapted microorganisms. This may explain why there are only few documented examples of active $\mathrm{pH}$ adjustment by organic acid production in free-living fungi $[21,23]$ and to our knowledge no active $\mathrm{pH}$ regulation by alkaline production has ever been observed in fungi. This implies that the $\mathrm{pH}$-buffering characteristics of attine fungus gardens are relatively unique. Although the chemistry of the garden buffering mechanism is unknown, its value of ca. 20 mekv/L is comparable to the $\mathrm{pH}$ buffering capacity of human blood (37 mekv/L; [28]) and much higher than any value observed outside metazoan bodies - cf. ocean water with $2.4 \mathrm{mekv} / \mathrm{L}$ [29] or soil with $2.2 \mathrm{mekv} / \mathrm{L}$ [30].
Although the production and secretion of buffering agents may impose significant metabolic costs, this may be sustainable because domestication implies that the ants provision the fungus with ad libitum resources. The benefits of buffering at a constant $\mathrm{pH}$ of ca. 5.2 might then be that this value represents a compromise between enhancing efficiency of degradation enzymes and discouraging the growth of parasitic microorganisms that infect fungus gardens [10,31]. If such dynamic equilibrium would exist, it might imply that acidification by the ants and/or the symbiont can be maintained continuously because $\mathrm{pH}$-buffering ensures the necessary stability required for vital fungus garden functions. It seems unlikely that fungal buffering compounds are primarily targeted towards neutralizing the antimicrobial metapleural gland secretions of $\mathrm{pH} 2.5[9,10]$, as a recent study has shown that the ants apply these secretions in very small portions and with great care [32]. The main cause of fungus gardens acidification thus remains unknown, but may be based on a combination of fungal secretions and contributions from other glands of the farming ants.

\section{The evolution of proteinase activity in the fungal symbionts}

Fungi normally produce a wide range of proteolytic enzymes to degrade substrate proteins. The fungal symbionts of lower attines that we investigated (four species from three different genera) had almost exclusively metalloproteinase activity, and virtually no serine proteinase activity. The known phylogenies of attine symbionts $[4,33,34]$ (see also Figure 2) indicate that the lower attine ants rear a paraphyletic group of symbionts that also includes closely related free-living fungi. This implies that we expect these symbionts to have similar enzyme profiles as free-living fungi, which was recently confirmed over a wide range of garden symbionts by De Fine Licht et al. [25]. Our observations thus indicate that the production of metalloproteinases may be an ancestral trait among the attine ant symbionts and suggest that metalloproteinase activity has been evolutionarily conserved while the $\mathrm{pH}$ optimum has shifted (or in some cases expanded) from values of ca. 6.0 for the lower attine ant symbionts to values of ca. 5.2 in the higher attine ant and leaf-cutting ant symbionts, which coincide with the acid $\mathrm{pH}$ that these ants maintain in their gardens $[9,10]$. The most parsimonious explanation for these findings is that the free-living relatives of the fungal symbionts would also have proteinases with $\mathrm{pH}$ optima of ca. 6, as there seems to be no reason to assume that initial fungus domestication events happened in very acid forest soils. If anything, the average free-living Lepiotaceous fungi prefer mull soils with $\mathrm{pH}$ values of at least 6.0 [6]. However, the symbionts of 
higher attine and leaf-cutting-ants, which have a long evolutionary history as domesticated symbionts, the symbionts of lower attine ants are repeatedly acquired from free-living populations and would thus have had much less time to evolve proteinases with adjusted activity profiles at lower $\mathrm{pH}$.

While metalloproteinase activity appears to be conserved throughout, it appears not to have been upregulated in garden symbionts of basal higher attine ants. The monophyletic group of fungal symbionts reared by S. amabilis, T. cf. zeteki and T. sp3, had reduced metalloproteinase activity and significantly enhanced serine proteinase activity (Figure 2). It has previously been shown that the enzymatic profiles of attine ant symbionts may have a certain amount of plasticity in response to the plant substrate that they grow on [35]. However, differences in the properties of proteinases found in fungal gardens were unlikely to be caused by variations in food substrate composition, as all lab colonies used in the present study were provided with the same leaf material. It seems likely therefore, that the proteinase activity profiles that we obtained have a significant genetic component. Phylogenies of attine ants show that $S$. amabilis is more closely related to $T$. cf. zeteki than to T. cornetzi ( $\mathrm{T}$ Schultz, pers. comm.), which together with our present results suggests that these ants may have co-evolved with the proteinase activity profiles of their cultivars.

Our quantitative analyses showed that the respective activities of metallo- and serine proteinases in gardens of higher attine ants (including the leaf-cutting ants) tend to be negatively correlated (Figure 1). In most symbionts, the split is very pronounced, with almost complete specialization on one of the two classes of proteinases, although the symbiont of $T$. cornetzi colony 17 is an exception showing almost equal, intermediate activities of the two proteinase classes. This suggests that there may be a trade-off in the expression of proteinases and that there may be adaptive reasons of substrate processing that make the production of either serine- or metalloproteinases most appropriate. Both serine proteinases and metalloproteinases are very widespread in nature and are involved in a wide variety of biological processes. Enzymes belonging to these classes vary significantly in substrate specificity which may correspond to the requirements of fungal ecological niches [36]. One explanation for the shift towards almost exclusive serine proteinase activity might therefore be that the ants that rear these symbionts forage for leaf and flower material that can be more effectively degraded by serine proteinases [37].

Recent studies by Mikheyev et al. [38,34] have shown that North American Trachymyrmex rear at least four different species of fungal symbiont, whereas virtually all leaf-cutting ants throughout Latin America appear to rear a single species (Leucocoprinus gongylophorus (Möller) (http://www.indexfungorum.org), which has likely been derived secondarily no longer than 2-3 million years ago and swept horizontally through most if not all species of Acromyrmex and Atta leaf-cutting ants, who themselves had their last common ancestor 8-12 million years ago [39]. Whether this selective sweep had any connection with the symbiont being a strain with upregulated activity of metalloproteinases is presently unknown, but it would be of interest if rare leaf-cutting ants could be found that rear gardens that are more closely related to the serine protease producing Trachymyrmex and Sericomyrmex symbionts.

We have so far assumed that the measured proteinase activities originate from enzymes produced by the fungal symbiont of the ants. They could also possibly originate from the additional microorganisms found in the fungus gardens of attine ants [40-42]. However, as earlier mentioned [25], the fungal symbiont comprises by far the largest microbial biomass fraction of gardens, so that contributions from other microorganisms should be quantitatively negligible unless they would be specialized symbionts selected for specific enzyme production (for which there is no indication so far). Furthermore, we find consistent patterns of proteinase activity among fungus gardens of the same strain, but differences between strains, which would imply that fungal strains should be obligatorily associated with specific microbial floras if these were to be the predictable sources of the proteinase activities that we measured. Also this would only make sense if these microbial floras would have coevolved symbiont adaptations with specific functions. We cannot exclude that such additional symbionts might exist, but find it hard to base our discussion on such assumption in the absence of any evidence.

\section{Do leaf-cutting ants suffer from proteinase inhibitors in the leaves that they cut?}

Plants produce substantial amounts of proteinase inhibitors to reduce their nutritional value for herbivores [43], who in turn have evolved various mechanisms to circumvent such proteinase inhibitors. As herbivory in attine ants is indirect, it would seem most likely that the ants have come to rely on their fungal symbiont to evolve compensatory measures against proteinase inhibitors, but this may not have been an easy process as the ancestral leucocoprinous fungi that the ants domesticated are leaf litter saprotrophs [6] rather than plant pathogens, and can thus not be expected to have possessed pre-adaptations that enabled them to easily overcome the defense mechanisms present in live plant material. 
Putative symbiont adaptations to tackle proteinase inhibitors are unlikely to have arisen in Trachymyrmex or Sericomyrmex symbionts as these ants mostly use shed flowers and fragments of fallen leaves that are unlikely to be actively defended [37]. Only the most evolutionary advanced leaf-cutting ants, and in particular the genus Atta, cut fresh leaves at a large enough scale of defoliation to encounter significant plant defenses by proteinase inhibitors. It would thus be interesting to measure proteinase inhibition in naturally obtained live plant material that Trachymyrmex, Sericomyrmex, Acromyrmex and Atta workers provide to their symbionts, to see whether any of these might be specifically targeted towards either serine- or metalloproteinases.

\section{Conclusions}

We have obtained clear indications that the $\mathrm{pH}$ optima of proteinases produced by the fungal symbionts of higher attine ants and leaf-cutting ants have become adapted to the acid $\mathrm{pH}$ conditions of fungus gardens relative to the surrounding soil. We have also shown that fungus gardens in general have very high $\mathrm{pH}$ buffering capacities, and that the production of serine- and metalloproteinases has a distinct phylogenetic pattern, suggesting at least some form of coevolution with the ant farmers. Our data further suggest that trade-offs may exist with respect to the simultaneous production of serine and metalloproteinases across the different species of fungal symbionts. These results are consistent with the symbiosis being constrained by nitrogen availability, due to the low N/C ratio of the plant substrates of fungus gardens [44].

\section{Methods}

There are four main catalytic classes of proteolytic enzymes: aspartic-, cysteine- (thiol-), serine-, and metalloproteinases [45]. It has been inferred that aspartic proteinases are mostly active under acidic $\mathrm{pH}$ conditions, that metallo- and serine proteinases usually work optimally under alkaline conditions, and that cysteine proteinase activity is high over a broader range $(\mathrm{pH} 4-7)$ [46]. We compared both the total and the class-specific proteolytic activity of attine ant symbionts and their free-living relatives across a gradient of different $\mathrm{pH}$ conditions.

\section{Sample material, fungal tissue extract preparation and buffering}

Colonies of fungus-growing ants Apterostigma collare (nest number Apcol1), Myrmicocrypta ednaella (Myred1, Myred2), Mycocepurus smithii (Mycsmi9, Mycsmi15, Mycsmi32), Cyphomyrmex costatus (Cycos6, Cycos9, Cycos16), Cyphomyrmex longiscapus (Cylon5, Cylon12, Cylon24), Sericomyrmex amabilis (Serama7, Serama8, Serama12), Trachymyrmex cornetzi (Trcor1,
Trcor3, Trcor4, Trcor10), Trachymyrmex sp. 3 (Trsp3-3, Trsp3-6), Trachymyrmex cf. zeteki (Trzet2, Trzet3, Trzet6), Acromyrmex echinator (Acech322), Acromyrmex octospinosus (Acoct367), Atta colombica (Atcol27), Atta sexdens (Atsex1), and Atta cephalotes (Atcep16) were collected in Gamboa, Panama and maintained under standard laboratory conditions at ca. $25^{\circ} \mathrm{C}$ and $60-70 \%$ $\mathrm{RH}$. The ants were supplied with oatmeal (Apterostigma, Mycocepurus and Cyphomyrmex), oatmeal and fragmented bramble leaves (Myrmicocrypta, Sericomyrmex and Trachymyrmex) or entire bramble leaves, dry rice and pieces of apple (Atta and Acromyrmex).

Strains of non-symbiotic fungi Agaricus bisporus, Pleurotus ostreatus, P. pulmonarous and Lentinula edodes, which belong to the same fungal order as the leaf-cutting ant symbiont (Agaricales), were obtained from the Department of Mycology and Algology, Moscow State University, Russia. Pure cultures of Leucocoprinus gongylophorus were obtained by inoculating mycelium collected from fungus gardens on potato dextrose agar plates and subsequent incubation at $25^{\circ} \mathrm{C}$. Fungal cultures were maintained on wort-agar medium and Czapek medium enriched by tryptone $(10 \mathrm{~g} / \mathrm{L})$ and peptone $(10 \mathrm{~g} / \mathrm{L})$.

Fungi are known to modify environmental $\mathrm{pH}$ by producing $\mathrm{pH}$ regulating compounds. To detect whether the acidity of fungus garden extracts was due to instantaneous acid production or active buffering, we examined the buffering properties of the extracts. First buffering abilities of the fungal extracts were determined by mixing one $\mu \mathrm{l}$ of fungus garden water extract $(1 \mathrm{~g}$ in $1 \mathrm{ml})$ with an equal volume of $0.04 \mathrm{M}$ acid solution (containing phosphoric, boric and acetic acids) or an alkaline solution $(0.02 \mathrm{M} \mathrm{NaOH})$, and the resulting $\mathrm{pH}$ levels were measured as color changes on $\mathrm{pH}$ test paper. The resulting $\mathrm{pH}$ change was compared to the $\mathrm{pH}$ change obtained using a control acid solution diluted with an equal volume of distilled water, or an alkaline solution two times diluted with distilled water. Next we determined the buffering capacity of the extracts, and compared it to the buffering capacity of extracts made from related nonsymbiotic basidiomycete fungi. To measure the approximate buffering capacity of the different fungal species, one gram of fungal biomass or one gram of fungus garden material was homogenized with a pestle in $1 \mathrm{ml}$ of distilled water. Samples were centrifuged (5 min, 5200g) and the supernatant was used for buffer capacity measurements, i.e. the quantity of $1 \mathrm{M} \mathrm{NaOH}$ that needed to be added to $1 \mathrm{ml}$ the fungus extract in order to change the $\mathrm{pH}$ of the suspension by one unit.

\section{Proteolytic activity assays}

Proteolytic activity was measured spectrophotometrically using azocasein (Sigma-Aldrich Co) and the chromogenic 
p-nitroanilide substrates: Glp-Ala-Ala-Leu-pNa, N-benzoyl-Arg-pNa, and Suc-Ala-Ala-Pro-Phe-pNa (prepared by The State Research Institute of Genetics and Selection of Industrial Microorganisms, Russia). Total and class-specific proteinase activity towards azocasein was tested by determining the rate of hydrolysis after homogenizing pieces of fungus garden material with a pestle in an Eppendorf tube using 2.5 volumes (w/v) of distilled water (in order to keep the natural $\mathrm{pH}$ of the sample). Samples were centrifuged at $8000 \mathrm{~g}$ for 15 minutes and the supernatant transferred to a clean tube. Ten $\mu$ l of extract was mixed with $15 \mu$ l of $2 \%$ $(\mathrm{w} / \mathrm{v})$ azocasein solution and incubated for 1 hour at $26^{\circ} \mathrm{C}$. The reaction was terminated with the addition of $120 \mu \mathrm{l}$ of $10 \%$ TCA after which the suspension was centrifuged for 5 minutes at $14000 \mathrm{~g}$ and $140 \mu \mathrm{l}$ of supernatant was added to an equal volume of freshly prepared $\mathrm{NaOH}(1 \mathrm{M})$. Absorbance was measured at $440 \mathrm{~nm}$ using a VERSA max $_{\text {microplate reader. Reac- }}$ tions in control samples were terminated immediately after adding azocasein. The difference between treatment and control absorbance $\left(\mathrm{A}_{440}\right.$, at $\mathrm{t}^{\circ} \mathrm{C} 26^{\circ} \mathrm{C}$, 1 hour) was used as a relative measure of enzyme activity. All measurements were performed four times producing means that are presented \pm SE.

In order to measure class-specific proteinase activity, the assays were performed in the presence of a protease inhibitor that specifically targets proteases of a certain class. The decrease in activity caused by the inhibitor was used as the class-specific activity value. The inhibition assays were performed using azocasein as described above. $10 \mu \mathrm{l}$ of sample was preincubated for 3 hours at room temperature with $1 \mu \mathrm{l}$ of inhibitor resulting in the following final concentrations of the inhibitors (all purchased from Sigma Chemicals Co): For serine proteinase inhibition we used phenylmethane-sulphonul-fluoride (PMSF, $0.57 \mathrm{mM}$ ), tosyl lysil chlormethyl ketone (TLCK, $10 \mu \mathrm{M})$ and tosyl phenilalanine chlormethyl ketone (TPCK, $10 \mu \mathrm{M}$ ). For cysteine proteinase inhibition we used L-trans-epoxysuccinyl-leucyl-amide-4-guanidinobutane $(\mathrm{E} 64,5 \mu \mathrm{M})$. Activity was also measured after the addition of thyol protecting agent DTT $(10 \mathrm{mM})$, which may increase the activity of cysteine proteinases. For metalloproteinase inhibition we used ethylendiaminetetraacetic acid (EDTA, $8 \mathrm{mM}$ ) and for aspartyl proteinase inhibition we used pepstatin $(2 \mu \mathrm{M})$.

Serine proteinases can be further divided into subclasses based on which substrates they are able to degrade. To determine which sub-classes of serine proteinases were active in fungal gardens, we measured activity towards p-nitroanilides after mixing $5 \mu \mathrm{l}$ of fungal garden extract, $5 \mu \mathrm{l}$ of substrate $(10 \mathrm{mg} / \mathrm{ml})$ and 200 $\mu \mathrm{l}$ of potassium phosphate buffer $(0.1 \mathrm{M})$ of $\mathrm{pH} 5.0$ or 7.0 and incubating the reaction mixture at $26^{\circ} \mathrm{C}$. The change in absorbance was analyzed using a VERSA $\mathrm{Vax}_{\max }$ microplate reader spectrophotometer at $410 \mathrm{~nm}$. The linear part of the obtained kinetic curve (the dependence of absorbance on time) was used to calculate the enzyme activity.

The effect of $\mathrm{pH}$ on total and class-specific proteolytic enzyme activity was measured across a pH range of 3 to 8 (actual measurements at 3.0, 4.0, 5.0, 5.2, 6.0, 7.0, 7.5, 8.0) using 0.2 M Britton - Robinson buffers (A mixture of $0.4 \mathrm{M}$ phosphoric-, $0.4 \mathrm{M}$ acetic-, and $0.2 \mathrm{M}$ boric acid was mixed with different quantities of $0.2 \mathrm{M} \mathrm{NaOH}$ to give buffer solutions with the required $\mathrm{pH}$ values). The relatively high molarity of the buffers was used to make the natural buffering capacity of the extracts negligible compared to the experimentally induced ones.

To measure the $\mathrm{pH}$ dependent proteolytic activity of non-symbiotic fungi, culture fluid of $A$. bisporus was used. Modified Czapek medium $\left(0.7\right.$ g $\mathrm{KH}_{2} \mathrm{PO}_{4}, 0.3 \mathrm{~g}$ $\mathrm{K}_{2} \mathrm{HPO}_{4} \cdot 3 \mathrm{H}_{2} \mathrm{O}, 0.5 \mathrm{~g} \mathrm{MgSO}_{4} \cdot 7 \mathrm{H}_{2} \mathrm{O}, 0.01$ g FeSO $4 \cdot 7 \mathrm{H}_{2} \mathrm{O}$, $23.3 \mathrm{~g}$ casein in $1 \mathrm{~L} \mathrm{H}_{2} \mathrm{O}$ ) was inoculated with mycelium from seven days old plated fungus culture and incubated for six days on a rotary shaker $\left(130 \mathrm{rpm}, 24^{\circ} \mathrm{C}\right)$. Culture liquid was centrifuged $(14000 \mathrm{~g}, 20 \mathrm{~min}$ ) and filtered through filter paper. After adding sodium azide ( $8 \%$ water solution, $2.5 \mu \mathrm{l}$ to $1 \mathrm{ml}$ of culture liquid) to prevent contamination, fifty $\mu$ l of culture liquid was mixed with $100 \mu \mathrm{l}$ of Britton - Robinson buffer (0.1M, pH range from 3 to 8 ; actual measurements at $3,4,5,5.2$, $6,7,7.5,8)$ and $150 \mu \mathrm{l}$ of $0.5 \%$ water azocasein solution. Reactions were kept overnight $\left(37^{\circ} \mathrm{C}\right)$ because of relatively low enzyme activity and then terminated by adding $300 \mu \mathrm{l}$ of $10 \% \mathrm{TCA}$. The reactions were placed at $4^{\circ}$ $\mathrm{C}$ for $30 \mathrm{~min}$ and then centrifuged for $20 \mathrm{~min}(5200 \mathrm{~g})$. $400 \mu \mathrm{l}$ of suspension was mixed with an equal volume of freshly prepared $\mathrm{NaOH}(0.5 \mathrm{M})$ and absorbance at $440 \mathrm{~nm}$ was measured using a spectrophotometer (Genesys 10 - UV). The reactions of the control samples were terminated with TCA immediately after adding azocasein. The difference between the absorbance of the treatment and control samples was used as a relative measure of enzyme activity. All measurements were performed three times and presented as means \pm SE. Classspecific proteinase activity $\mathrm{pH}$ optima were measured in the presence of a protease inhibitors PMSF and EDTA as described above.

Proteolytic activities were finally compared across the different stages of advancement of the symbiosis (lower attine ants, higher attine ants, leaf-cutting ants).

\section{Phylogenetic analysis}

Sequencing of the LSU rRNA gene and the Elongation Factor 1-alpha gene of the fungal symbionts was done by extracting DNA by the Chelex method [47]. Small amounts of fungal tissue were ground in $200 \mu \mathrm{l}$ of $10 \%$ 
Chelex-100 and heated for $15 \mathrm{~min}$ at $95^{\circ} \mathrm{C}$. The samples were centrifuged for $3 \mathrm{~min}$ at 10,000g after which $1 \mu \mathrm{l}$ of supernatant was used for PCR. The primer pair LROR 5'-ACC CGC TGA ACT TAA GC-3' and LR5 5'-TCC TGA GGG AAA CTT CG-3' was used to amplify a fragment of the LSU rRNA gene of about $920 \mathrm{bps}$, using the following PCR scheme: one cycle of $95^{\circ} \mathrm{C}$ for $5 \mathrm{~min}$, then 35 cycles of $95^{\circ} \mathrm{C}$ for $20 \mathrm{sec}, 56^{\circ} \mathrm{C}$ for $30 \mathrm{sec}$, and $72^{\circ} \mathrm{C}$ for $1.5 \mathrm{~min}$, ending with one cycle of $72^{\circ} \mathrm{C}$ for 7 min. The primer pair EF1a-F 5'-GTT GCT GTC AAC AAG ATG GAC ACT AC-3'. [48] and EF1a-R5 5'-CAG GCA ATG TGG GCT GTG TGA CAA TC-3' was used to amplify a fragment of the Elongation factor 1-alpha gene of about $820 \mathrm{bps}$, using a PCR scheme similar to the one above, although for some of the samples the annealing temperature had to be decreased to $50^{\circ} \mathrm{C}$ in order to obtain a PCR product. PCR products were sequenced by Eurofins MWG Operon. Nucleotide sequence data are deposited in GenBank with Accession Numbers HQ191224-HQ191277.

The gene sequences were aligned with Clustal W [49], and after deletion of regions that could not be unambiguously aligned, a phylogeny was constructed by maximum-likelihood PhyML-aLRT [50]. The nucleotide substitution model was GTR [51] and the transition/ transversion ratios, the proportion of invariable sites and the Gamma distribution parameter were estimated by maximizing the likelihood of the phylogeny. The substitution rate category was set to four, and the input tree to be refined by the maximum-likelihood algorithm was set to BIONJ. The aLRT statistics were performed using the non-parametric Shimodaira-Hasegawa-like procedure. Two of the fungal colonies (Trsp3-6 Trzet6) died during the experiment, so that only the LSU gene could be used for these two samples when constructing the phylogenetic tree.

\section{Acknowledgements}

We thank Sylvia Mathiasen and Charlotte Olsen for help with the maintenance of ant colonies, the Smithsonian Tropical Research Institute, Panama, for providing logistic help and facilities to work in Gamboa, and the Autoridad Nacional del Ambiente y el Mar (ANAM) for permission to sample ants in Panama and to export them to Denmark. We also thank Ulrich Mueller for valuable comments on the manuscript, and S.A. Semenova, and Ya.E. Dunaevsky for insightful comments and discussions of the experients. MS and JJB were supported by the Danish National Research Foundation and MS also by the Carlsberg Foundation, TAS was supported by the Erasmus Mundus programme and a Russian Research Foundation Grant (070400559), and DPH was supported by a Marie Curie Intra-european fellowship.

\section{Author details}

${ }^{1}$ Centre for Social Evolution, Department of Biology, University of Copenhagen, Universitetsparken 15, DK-2100 Copenhagen, Denmark. ${ }^{2}$ Department of Ecology and Agriculture, University of Copenhagen, Thorvaldsensvej 40, DK-1871 Frederiksberg C, Denmark. ${ }^{3}$ A.N. Belozersky Institute of Physico-Chemical Biology, Moscow State University, Leninskie
Gory 1, Moscow 119992, Russia. ${ }^{4}$ Current address: Museum of Comparative Zoology, Harvard University, 26 Oxford Street, Cambridge MA 02138, USA.

\section{Authors' contributions}

TAS, JJB, DPH and MS conceived of the study. TAS carried out the protease activity and buffering capacity assays. TAS and MS made the phylogeny. TAS, JJB and MS wrote the manuscript with input from DPH. All authors read and approved the final manuscript.

Received: 6 September 2010 Accepted: 19 January 2011

Published: 19 January 2011

\section{References}

1. Hentschel U, Steinert M: Symbiosis and pathogenesis: common themes, different outcomes. Trends Microbiol 2001, 9(12):585.

2. Adams KL, Palmer JD: Evolution of mitochondrial gene content: gene loss and transfer to the nucleus. Mol Phylogenet Evol 2003, 29:380-395.

3. Paracer S, Ahmadjian V: Symbiosis: An Introduction to Biological Associations. New York: Oxford University Press; 2000.

4. Mueller UG, Rehner SA, Schultz TR: The evolution of agriculture in ants. Science 1998, 281:2034-2038.

5. Schultz TR, Mueller UG, Currie CR, Rehner SA: Reciprical illumination: A comparison of agriculture in humans and fungus-growing ants. In InsectFungal Associations Ecology and Evolution. Edited by: Vega F, Blackwell M. New York: Oxford University press; 2005:149-190.

6. Vellinga EC: Ecology and distribution of Lepiotaceous fungi (Agaricaceae) - A rewiew. 2004, 78:273-299, Nova Hedwigia.

7. Maschwitz U, Koob K, Schildknecht H: Ein Beitrag zur Funktion der Metathoracaldrüse der Ameisen. J Insect Physiol 1970, 16:387-404, (in german).

8. Beattie AJ, Turnbull C, Hough T, Knox RB: Antibiotic production: a possible function for the metapleural glands of ants (Hymenoptera: Formicidae). Ann Entomol Soc Am 1986, 79:448-450.

9. Ortius-Lechner D, Maile R, Morgan ED, Boomsma JJ: Metapleural gland secretion of the leaf-cutting ant Acromyrmex octospinosus: New compounds and their functional significance. J Chem Ecol 2000, 26(7):1667-1683

10. Bot ANM, Ortius-Lechner D, Finster K, Maile R, Boomsma JJ: Variable sensitivity of fungi and bacteria to compounds produced by the metapleural glands of leaf - cutting ants. Insectes Soc 2002, 49:363-370.

11. Pinto-Tómas AA, Anderson MA, Suen G, Stevenson DM, Chu FST, Cleland WW, Weimer PJ, Currie CR: Symbiotic nitrogen fixation in the fungus gardens of leaf-cutting ants. Science 2009, 326:1120-1123.

12. Little AEF, Murakami T, Mueller UG, Currie CR: Defending against parasites: fungus-growing ants combine specialized behaviours and microbial symbionts to protect their fungus gardens. Biol Lett 2006, 2(1):12-16, 22,

13. Rodrigues A, Pagnocca FC, Bacci M, Hebling MJA, Bueno OC, Pfenning LH: Variability of non-mutualistic filamentous fungi associated with Atta sexdens rubropilosa nests. Folia Microbiol (Praha) 2005, 50(5):421-425.

14. St Leger RJ, Nelson JO, Screen SE: The entomopathogenic fungus Metarhizium anisopliae alters ambient $\mathrm{pH}$, allowing extracellular protease production and activity. Microbiology 1999, 145:2691-2699.

15. Kunze UR, Schwedt G: Grundlagen der qualitative und quantitative Analyse. Moscow: Mir; 1997.

16. levleva EV, Revina TA, Kudryavtseva NN, Sofin AV, Valueva TA: Extracellular proteinases from the phytopathogenic fungus Fusarium culmorum. Prikl Biokhim Microbiol 2006, 42(3):298-303.

17. Hoegl L, Ollert M, Korting HC: The role of Candida albicans secreted aspartic proteinase in the development of candidoses. J Mol Med 1996, 74(3):135-142.

18. Salvesen GS, Nagase H: Inhibition of proteolytic enzymes. In Proteolytic enzymes: A practical approach. Edited by: Beynon R, Bond JS. Oxford University Press; 2001:105-130.

19. Lyublinskaya LA, Haidu I, Balandina GN, Filippova IY, Markaryan AN, Lysogorskaya EN, Oksenoit ES, Stepanov VM: $p$-Nitroanilides of pyroglutamylpeptides as chromogenic substrates of serine proteinases. Bioorgan Khim 1987, 13:748-753, (in russian).

20. Thomas KC, Hynes SH, Ingledew WM: Influence of medium buffering capacity on inhibition of Saccharomyces cerevisiae growth by acetic and lactic acids. Appl Environ Microbiol 2002, 68(4):1616-1623. 
21. Lapeyrie F: Oxalate synthesis from soil bicarbonate by the mycorrhizal fungus Paxillus involutus. Plant Soil 1988, 110(1):3-8.

22. Penalva MA, Herbert NA: Regulation of Gene Expression by Ambient pH in Filamentous Fungi and Yeasts. Microbiol Mol Biol Rev 2002, 66(3):426-446.

23. Magnuson JK, Lasure LL: Organic acid production by filamentous fungi. In Advances in Fungal Biotechnology for Industry, Agriculture and Medicine. Edited by: Lange J\&L. Kluwer Academic/Plenum Publishers; 2004:307-340.

24. Marzluf G: Genetic regulation of Nitrogen Metabolism in Fungi. Microbiol Mol Biol Rev 1997, 61(1):17-31.

25. De Fine Licht HH, Schiøtt M, Mueller UG, Boomsma JJ: Evolutionary transitions in enzyme activity of ant fungus gardens. Evolution 2010 64:2055-2069

26. Hulanicki A: Reactions of Acids and Bases in Analytical Chemistry.Edited by: Masson MR. Horwood; 1987:

27. Scorpio R: Fundamentals of Acids, Bases, Buffers \& Their Application to Biochemical Systems. Dubuque. Kendall-Hunt Pub. Co; 2000.

28. Ellison G, Straumfjord JV Jr, Hummel JP: Buffer capacities of human blood and plasma. Clin Chem 1958, 4:452-461.

29. Mitchell H, Rakestraw NW: The buffer capacity of sea water. Biol Bull 1933, 65:437-451.

30. Yong RN: Geoenvironmental engineering: Contaminated soils, pollutant fate, and mitigation. Boca Raton. CRS Press; 2001.

31. Papa J, Papa F: Bacteriological inhibition in the nests of Acromyrmex octospinosus Reich. Bull Soc Pathol Exot Filiales 1982, 75(4):415-25.

32. Fernandez-Marin H, Zimmerman JK, Rehner SA, Wciso WT: Active use of the metapleural glands by ants in controlling fungal infection. Proc Biol Sci 2006, 273:1689-1695.

33. Vo TL, Mueller UG, Mikheyev AS: Free-living fungal symbionts (Lepiotaceae) of fungus-growing ants (Attini: Formicidae). Mycologia 2009, 101(2):206-210.

34. Mikheyev AS, Mueller UG, Abbot P: Comparative Dating of Attine Ant and Lepiotaceous Cultivar Phylogenies Reveals Coevolutionary Synchrony and Discord. Am Nat 2010, 175:E126-E133.

35. Schiøtt M, De Fine Licht HH, Boomsma JJ: Towards a molecular understanding of symbiont function: Identification of a fungal gene for the degradation of xylan in the fungus garden of leaf-cutting ants. BMC Microbiology 2008, 8:40.

36. St Leger RJ, Joshi L, Roberts DW: Adaptation of proteases and carbohydrases of saprotrophic, phytopathogenic and entomopathogenic fungi to the requirements of their ecological niches. Microbiology 1997, 147:1983-1992.

37. De Fine Licht HH, Boomsma JJ: Forage collection, substrate preparation, and diet composition in fungus-growing ants. Ecol Entomol 2010, 35:259-269.

38. Mikheyev AS, Mueller UG, Boomsma JJ: Population genetic signatures of diffuse co-evolution between leaf-cutting ants and their cultivar fungi. Mol Ecol 2007, 16:209-216.

39. Schultz TR, Brady SG: Major evolutionary transitions in ant agriculture. Proc Natl Acad Sci USA 2008, 105(14):5435-5440.

40. Bacci M, Ribeiro JSB, Casarotto MEF, Pagnocca FC: Biopolymer-degrading bacteria from nests of the leaf-cutting ant Atta sexdens rubropilosa. Braz J Med Biol Res 1995, 28:79-82.

41. Carreiro SC, Pagnocca FC, Bueno OC, Bacci M, Hebling MJA, Silva OA: Yeasts associated with nests of the leaf-cutting ant Atta sexdens rubropilosa Forel, 1908. Anton Leeuw Int J G 1997, 71(3):243-248.

42. Rodrigues A, Bacci M, Mueller UG, Ortiz A Pagnocca FC: Microfungal 'weeds' in the leafcutter ant symbiosis. Microb Ecol 2008, 56:604-614

43. Chen MS: Inducible direct plant defense against herbivores: A review. Insect Science 2008, 15:101-114.

44. Begon M, Harper JL, Townsend CR: Ecology. Oxford: Blackwell Science Ltd; 31996.

45. Rawlings ND, Barrett AJ: Evolutionary families of peptidases. Biochem J 1993, 290:205-218

46. Oliveira AS, Xavier-Filho J, Sales MP: Cysteine proteinases and cystatins. Braz Arch Biol Technol 2003, 46(1):91-104.

47. Walsh PS, Metzger DA, Higuchi R: Chelex 100 as a medium for simple extraction of DNA for PCR-based typing from forensic material. Biotechniques 1991, 10:506-513.
48. Mikheyev AS, Mueller UG, Abbot P: Cryptic sex and many-to-one coevolution in the fungus-growing ant symbiosis. Proc Natl Acad Sci USA 2006, 103:10702-10706.

49. Thompson JD, Higgins DG, Gibson TJ: CLUSTAL W: improving the sensitivity of progressive multiple sequence alignment through sequence weighting, positions-specific gap penalties and weight matrix choice. Nucleic Acids Res 1994, 22:4673-4680.

50. Guindon S, Gascuel O: A simple, fast, and accurate algorithm to estimate large phylogenies by maximum likelihood. Syst Biol 2003, 52:696-704.

51. Tavaré L: Some probabilistic and statistical problems on the analysis of DNA sequences. American Mathematical Society: Lectures Mathematics Life Sciences 1986, 17:57-86.

doi:10.1186/1471-2180-11-15

Cite this article as: Semenova et al:. Evolutionary patterns of proteinase activity in attine ant fungus gardens. BMC Microbiology 2011 11:15.

\section{Submit your next manuscript to BioMed Central and take full advantage of:}

- Convenient online submission

- Thorough peer review

- No space constraints or color figure charges

- Immediate publication on acceptance

- Inclusion in PubMed, CAS, Scopus and Google Scholar

- Research which is freely available for redistribution

Submit your manuscript at www.biomedcentral.com/submit
Ciomed Central 